\title{
KANDUNGAN PROTEIN KASAR DAN SERAT KASAR PADA DAUN KACANG TANAH (Arachis hypogaea) YANG DIFERMENTASI DENGAN BAKTERI Enterobacter cloacae WPL 111 SEBAGAI BAHAN PAKAN ALTERNATIF IKAN
}

\author{
CONTENT OF CRUDE PROTEIN AND CRUDE FIBER IN PEANUT LEAVES (Arachis \\ hypogaea) WHICH IS FERMENTED BY Enterobacter cloacae WPL 111 AS ALTERNATIVE \\ FISH FEED STUFF
}

\author{
Karlina Hardianing Pangestu, Agustono dan Widya Paramita Lokapirnasari \\ Fakultas Perikanan dan Kelautan Universitas Airlangga \\ Kampus C Mulyorejo - Surabaya, 60115 Telp. 031-5911451
}

\begin{abstract}
Feed is an element that really support the activities of aquaculture, there for the feed that is available must be adequate and meet the needs of the fish. Efforts to reduce feed costs, some farmers use alternative feed ingredients as a substitute for feed ingredients. Peanut leaves in the form of flour can be used as fish feed in pellet form. Peanut is potential biological resources to be used as feed to the waste produce sufficient forage nutritional value. Peanut leaves nutrition consist of, the dry matter 96,2754\%, $29,7397 \%$ crude fiber, 17,2475\% crude protein (Unit Inspection Services Consulting and Training of Faculty of Veterinary Medical Laboratory Airlangga University, 2014).This research been used Completely Randomized Design (CRD) method with five treatments and four replications. The treatment used were control (P0), the provision of Enterobacter cloacae WPL $1115 \%$ (P1), 10\% (P2), 15\% (P3) and $20 \%$ (P4) with each repeated four times. Parameters observed were content of crude protein and crude fiber after fermentation for seven days in anaerob facultative. Data about the contain of crude protein and crude fiber obtained from this studied were analyzed with analysis of variants to determine the effect of treatment. Different between treatments were tested with Duncan;s multiple range test (DMRT). These results indicate that administration Enterobacter cloacae WPL 111 10\% gave significant effect of the increase in crude protein content in the fermented leaves peanut and administration Enterobacter cloacae WPL $1115 \%$ gave significant effect of the decrease in crude fiber content in the fermented leaves peanut. The suggested dosage to reduce the content of crude fiber and increase the crude protein content in the fermented leaves peanut is $10 \%$.
\end{abstract}

Keywords : Peanut leaves, Enterobacter cloacae WPL 111, crude protein, crude fiber

\section{Pendahuluan}

Pakan berperan sangat penting pada usaha budidaya perikanan, sehingga pakan yang tersedia harus memenuhi kebutuhan nutrisi ikan tersebut. Pakan memberikan kontribusi terbesar yaitu mencapai 60 sampai $70 \%$ dari total biaya produksi (Handajani, 2008). Salah satu upaya untuk mengurangi biaya pakan yaitu dengan pemanfaatan bahan baku pakan alternatif. Bahan pakan alternatif ikan pada umumnya berasal dari berbagai limbah yang kandungan nutrisinya masih dapat dimanfaatkan sebagai bahan pakan ikan. Limbah dari pertanian umumnya menpunyai kandungan protein yang rendah tetapi kandungan seratnya tinggi (Rokhmani, 2008).

Bahan pakan alternatif yang dapat dimanfaatkan adalah daun kacang tanah. Daun kacang tanah dapat dimanfaatkan sebagai pakan alternatif ikan karena kemudahan dalam memperoleh, mengelola dan tidak termasuk bahan makanan manusia. Kandungan nutrisi limbah daun kacang tanah yaitu berat kering $96,2754 \%$, serat kasar 29,7397\%, protein kasar 17,2475\% (Unit Layanan Pemeriksaan Laboratoris Konsultasi dan Penelitian FKH UA, 2014).

Fermentasi merupakan kemajuan bioteknologi dengan memanfaatkan mikroba dan merupakan cara alternatif optimalisasi daur ulang limbah pertanian (Muis dkk, 2008). Fermentasi dapat dilakukan dengan menggunakan mikroba, baik mikroba proteolitik maupun mikroba selulolitik (Hidayat dkk., 2006). Tujuan fermentasi adalah meningkatkan kadar protein, menurunkan serat kasar, dan meningkatkan kecernaan bahan pakan yang mengandung ligno-selulosa (Soundstol dan Coxworth, 1984 yang dikutip oleh Sovia, 2002).

Serat kasar yang tinggi menjadi faktor pembatas pemanfaatan bahan-bahan hasil samping agroindustri. Kandungan selulosa pada 
serat kasar merupakan komponen utama penyusun dinding sel yang merupakan polimer glukosa yang dapat dipecah melalui hidrolisis asam dan enzimatis (Murni et al., 2008). Keberadaan lignin dan hemiselulosa merupakan penghambat utama dalam hidrolisis selulosa. Hasil fermentasi diharapkan terjadi peningkatan terhadap kualitas bahan pakan yang akan digunakan sebagai campuran pakan ikan dan mampu meningkatkan pertumbuhan ikan (Widiastuti, 2007).

Pada penelitian ini digunakan bakteri selulolitik Enterobacter cloacae WPL 111. Bakteri selulolitik menghasilkan enzim selulase yang akan menghidrolisis selulosa menjadi selobiosa dan glukosa. Bakteri selulolitik menghasilkan enzim selulase yang dapat menghidrolisis selulosa menjadi karbohidrat terlarut yang selanjutnya dapat dimanfaatkan oleh ternak sebagai sumber energi.

\section{Materi dan Metode}

Tempat dan Waktu Penelitian

Kegiatan penelitian ini telah dilakukan di Departemen Peternakan Fakultas Kedokteran Hewan Universitas Airlangga Surabaya pada bulan Agustus 2014.

Peralatan Penelitian

Peralatan yang digunakan dalam penelitian ini adalah kantong plastik ukuran 0,5 $\mathrm{kg}$, spuit, gelas ukur, timbangan digital, pisau, mesin penggiling pakan, $\mathrm{pH}$ paper, oven, nampan plastik dan sendok.

\section{Bahan Penelitian}

Bahan-bahan yang digunakan dalam penelitian ini adalah limbah daun kacang tanah. Bakteri yang digunakan dalam proses fermentasi merupakan bakteri selulolitik yaitu Enterobacter cloacae WPL 111 yang didapatkan dari Departemen Peternakan Fakultas Kedokteran Hewan Universitas Airlangga dengn kepadatan 2,22 Skala Mc Farland (6.66 x $108 \mathrm{CFU} / \mathrm{ml})$. Bahan penunjang lain dalam penelitian ini adalah tetes tebu dan akuades steril.

\section{Metode Penelitian}

Metode yang digunakan dalam penelitian ini adalah metode eksperimen untuk mengetahui kandungan protein kasar dan serat kasar pada daun kacang tanah yang difermentasi dengan Enterobacter cloacae WPL 111 dengan dosis yang berbeda. Penelitian ini menggunakan Rancangan Acak Lengkap (RAL) dengan lima perlakuan dan empat ulangan.
Prosedur Kerja

a. Pembuatan Tepung Daun Kacang Tanah

Daun kacang tanah dipisahkan antara batang dan daunnya, selanjutnya daun kacang tanah dikeringkan dalam oven dengan suhu $60^{\circ} \mathrm{C}$ selama 24 jam. Daun yang sudah kering digiling dengan ukuran $1 \mathrm{~mm}$ sehingga menjadi tepung. Tepung daun kacang tanah yang sudah kering dibagi dalam kantong pastik masing-masing sebanyak 50 gram.

\section{b. Pencampuran Tepung Daun Kacang Tanah} dengan Enterobacter

Tepung daun kacang tanah yang telah ditimbang sebanyak 50 gram dimasukkan dalam baki untuk dicampur dengan larutan fermentor. Pembuatan fermentor yaitu dengan mencampurkan aquades dan tetes tebu dengan dosis $3 \%$ dari jumlah tepung daun kacang tanah sampai merata, kemudian ditambahkan Enterobacter sesuai dengan dosis yang ditentukan pada perlakuan.

\section{c. Proses Fermentasi}

Tepung daun kacang tanah yang telah dicampur secara homogen dengan larutan fermentor dimasukkan dalam kantong plastik dan diikat. Proses fermentasi dilakukan pada suhu $34-37^{\circ} \mathrm{C}$ dan dalam suasana anaerob selama tujuh hari. Setelah proses fermentasi selesai, hasil tepung daun kacang tanah fermentasi tersebut diangin-anginkan kemudian dianalisis proksimat untuk mengetahui kandungan serat kasar dan protein kasar.

\section{Parameter Pengamatan}

Parameter utama yang diamati dalam penelitian ini adalah nilai kandungan protein kasar dan serat kasar. Nilai kandungan tersebut diketahui dengan melakukan analisis proksimat.

\section{Analisis Data}

Data yang diperoleh, diolah dengan menggunakan Analysis of Variant (ANOVA) untuk mengetahui ada tidaknya pengaruh perlakuan yang diberikan. Jika terdapat pengaruh maka dilakukan Uji Jarak Berganda Duncan dengan taraf nyata $\alpha=0,05$ untuk mengetahui perlakuan mana yang memberikan hasil tertinggi dan terendah (Kusriningrum, 2010).

\section{Hasil dan Pembahasa}

\section{a. Protein Kasar}

Kandungan protein kasar tertinggi adalah pada perlakuan P3 dimana P3 merupakan perlakuan penambahan Enterobacter $15 \%$, sedangkan perlakuan terendah yaitu P0 dimana 
P0 merupakan kontrol tanpa penambahan Enterobacter.

Tabel 1. Kandungan protein kasar berdasarkan bahan kering $100 \%$ pada daun kacang tanah yang difermentasi dengan bakteri selulolitik Enterobacter cloacae WPL 111.

\begin{tabular}{cc} 
Perlakuan & Protein kasar $(\%) \pm \mathrm{SD}$ \\
\hline P0 $(0 \%)$ & $17,2500 \mathrm{a} \pm 0,5000$ \\
P1 $(5 \%)$ & $19,7500 \mathrm{~b} \pm 0,5000$ \\
P2 $(10 \%)$ & $22,0000 \mathrm{c} \pm 0,8165$ \\
P3 $(15 \%)$ & $22,2500 \mathrm{c} \pm 0,9574$ \\
P4 $(20 \%)$ & $21,7500 \mathrm{c} \pm 0,5000$ \\
\hline
\end{tabular}

Keterangan

a,b,c : Superskrip yang berbeda pada kolom yang sama menunjukkan perbedaan yang nyata $(\mathrm{p}<0,05)$

\section{b. Serat Kasar}

Berdasarkan uji jarak berganda Duncan (Duncan's Multiple Range Test) didapatkan hasil kandungan serat kasar dari ke lima perlakuan diketahui P0 $(0 \%)$ memiliki kandungan serat kasar tinggi yang tidak berbeda nyata dengan perlakuan P3 (15\%) namun berbeda nyata dengan P1 (5\%), P2 (10\%) dan P4 (20\%). Kandungan serat kasar yang rendah yaitu P1 dengan penambahan Enterobacter 5\% tidak berbeda nyata dengan penambahan Enterobacter 20\% (P4).

Tabel 2. Kandungan serat kasar berdasarkan bahan kering $100 \%$ pada daun kacang tanah yang difermentasi dengan bakteri selulolitik Enterobacter cloacae WPL 111.

Perlakuan $\quad$ Serar Kasar $(\%) \pm$ SD

\begin{tabular}{lc}
\hline P0 $(0 \%)$ & $32,0000 \mathrm{c} \pm 0,0000$ \\
P1 $(5 \%)$ & $29,0000 \mathrm{a} \pm 1,1547$ \\
P2 $(10 \%)$ & $30,7500 \mathrm{~b} \pm 0,9574$ \\
P3 (15\%) & $31,0000 \mathrm{bc} \pm 0,0000$ \\
P4 $(20 \%)$ & $30,0000 \mathrm{ab} \pm 0,8165$ \\
\hline
\end{tabular}

Keterangan

a,b,c : Superskrip yang berbeda pada kolom yang sama menunjukkan perbedaan yang nyata $(\mathrm{p}<0,05)$

Berdasarkan hasil penelitian fermentasi daun kacang tanah dengan Enterobacter cloacae WPL 111 selama 7 hari menunjukkan bahwa penambahan Enterobacter cloacae WPL 111 pada setiap perlakuan menunjukkan perbedaan yang nyata terhadap peningkatan kandungan protein kasar daun kacang tanah jika dibandingkan dengan dosis penambahan Enterobacter cloacae WPL 111 0\% (P0) sebagai kontrol. Kandungan protein kasar yang tinggi terdapat pada dosis $15 \%$ (P3) dengan nilai $22,2500 \%$ yang tidak berbeda nyata dengan perlakuan pemberian dosis $10 \%$ (P2) dan pemberian dosis $20 \%$ (P4).

Apabila dilihat dari efisiensi penggunaan Enterobacter cloacae WPL

111 yang tepat adalah dosis $10 \%$ (P2), mengingat bahwa dosis $10 \%$ (P2) telah mampu meningkatkan kandungan protein kasar menjadi $22,0000 \%$ dengan memberikan nilai protein kasar yang tidak berbeda nyata dengan pemberian dosis yang lebih tinggi yaitu $15 \%$ (P3) yang dapat meningkatkan kandungan protein kasar menjadi 22,2500\% dan pemberian dosis $20 \%$ (P4) yang dapat meningkatkan kandungan protein kasar menjadi $21,7500 \%$.

Perkembangan dari mikroba tergantung pada karbon yang tersedia, dengan meningkatnya jumlah mikroba tersebut maka terjadi kompetisi diantara mikroba untuk mendapatkan karbon, sehingga ketersedian karbon menjadi faktor pembatas (Rifqiyah, 2005 dalam Rachmasari, 2011). Pada perlakuan P2 (10\%) mendapatkan hasil protein kasar yang tinggi dan dikatakan sebagai dosis yang efisien karena pada dosis ini mikroba dapat memperoleh sumber nutrisi dengan cukup dibandingkan dengan perlakuan P3 (15\%) dan P4 (20\%) yang tidak berbeda nyata dengan P2 (10\%) karena dengan meningkatnya jumlah mikroba dapat terjadi kompetisi diantara mikroba untuk mendapatkan nutrisi.

Bakteri Enterobacter cloacae WPL 111 merupakan mikroba yang merupakan protein sel tunggal yang dalam tubuhnya mengandung nitrogen. Jumlah koloni mikroba yang bertambah selama prosese fermentasi secara tidak langsung dapat meningkatkan kandungan protein kasar dari suatu bahan karena mikroba merupakan sumber protein sel tunggal (Wuryantoro, 2006 dalam Priskila, 2007). Menurut Sumarsih (2009) protein sel tunggal merupakan istilah yang digunakan untuk protein kasar murni yang berasal dari mikroorganisme bersel satu atau banyak yang sederhana seperti bakteri, khamir, jamur, ganggang dan protozoa. Mikroba menghasilkan enzim, Enterobacter cloacae WPL 111 menghasilkan enzim selulase yang secara tidak langsung dapat meningkatkan kandungan protein kasar pada daun kacang tanah karena 
enzim merupakan protein.

Berdasarkan hasil penelitian fermentasi daun kacang tanah dengan Enterobacter cloacae WPL 111 menunjukkan bahwa penambahan Enterobacter cloacae WPL 111 dengan dosis $5 \%$ (P1) memberikan hasil

penurunan serat kasar yang baik yaitu $29,0000 \%$ namun tidak berbeda nyata dengan dosis $20 \%$ (P4) yaitu 30,0000\%.

Bakteri yang digunakan dalam fermentasi ini adalah Enterobacter cloacae WPL 111 dengan kepadatan 2,22 Skala Mc Farland (6.66 x $108 \mathrm{CFU} / \mathrm{ml})$. Penurunan serat kasar pada penelitian ini disebabkan oleh Enterobacter cloacae WPL 111 yang merupakan bakteri selulolitik yang dapat memproduksi enzim selulase. Enzim selulase merupakan enzim kompleks yang terdiri dari endoselulose dan eksoselulose. Enzim ini akan memecah selulosa menjadi selobiosa. Enzim yang mendegradasi selulosa yaitu endoglukanase / karboksil metal sululase (endo - 1,4 - $\beta$ - glukanase), eksoglukanase / selobiohidrolase (ekso $-1,4-\beta-$ glikanase) dan selobiase ( $\beta$ - glukosidase) (Hardjo dkk., 1989; Schlege; dan Schmidt, 1994). Endoglukanase memecah unit gukosil dari selulo-oligosakarida/selulodekstrin.

Eksoglukanase memecah unit gukosil dari selulo-oligosakarida dengan melepaskan selobiosa, kemudian selobiase menghidrolisis selobiosa dan oligosakarida menjadi glukosa (Hardjo dkk., 1989).

\section{Kesimpulan}

Kesimpulan pada penelitian ini adalah : pemberian Enterobacter cloacae WPL 111 dapat meningkatkan kandungan protein kasar pada daun kacang tanah yang difermentasi dengan dosis optimal 10\%. Pemberian Enterobacter cloacae WPL 111 dapat menurunkan kandungan serat kasar pada daun kacang tanah yang difermentasi dengan dosis optimal 5\%. Dosis yang disarankan untuk menurunkan kandungan serat kasar dan meningkatkan kandungan protein kasar pada daun kacang tanah yang difermentasi adalah $10 \%$. Melakukan penelitian lebih lanjut dengan lama waktu fermentasi yang berbeda untuk mengetahui pengaruh lama fermentasi terhadap prningkatan kandungan protein kasar dan penurunan serat kasar pada fermentasi daun kacang tanah. Melakukan penelitian lebih lanjut yang mengarah kepada aplikasi langsung terhadap terapan pemanfaatan daun kacang tanah fermentasi pada ikan herbivore untuk melihat kualitas pakan secara kimiawi, fisika dan biologis yang di dalamnya meliputi kecernaan pakan dan pertumbuhan.

\section{Daftar Pustaka}

Handajani, H dan W. Wahju. 2010. Nutrisi Ikan. UMM Press. Malang. hal 57-78.

Hardjo, S., N.S. Indrasari., dan T . Bantacut. 1989. Biokonversi: Pemanfaatan Limbah Industri Pertanian. Pusat Antar Universitas. Institut Pertanian Bogor. Bogor.

Hidayat, N.,M,Padaga dan S. Suhartini. 2006. Mikrobiologi Industri. Andi Offset. Yogyakarta. hal 15-31.

Kusriningrum. 2010. Perancangan Percobaan. Airlangga University Press. Surabaya. hal 172.

Muis, A., C. Khairani., Sukarjo dan Y.P. Rahardja. 2008. Petunjuk Teknis Teknologi Pendukung Pengembangan Agribisnis Si Desa PAMI. Badan Penelitian dan Pengembangan Pertanian. Balai Pengkajian Teknologi Pertanian. Sulawesi Tengah. Hal 44.

Murni, R., Suparjo., Akmal dan B.L. Ginting. 2008. Buku Ajar Teknologi Pemanfatan Limbah Untuk Pakan. Laboratorium Makanan Ternak Fakultas Peternakan. Universitas Jambi. hal 28.

Priskila, F. 2007. Pengaruh penggunaan Kambucha Terhadap Protein Kasar dan Serat Kasar pada Fermentasi Daun Talas. Fakultas Kedokteran Hewan Universitas Airlangga. Surabaya.

Rokhmani, S. 2008. Peningkatan Nilai Gizi Bahan dari Limbah Pertanian Melalui Fermentasi Lokakarya Nasional Potensi dan Peluang Pengembangan Usaha Agribisnis Kelinci. Balai Penelitian Ternak. Bogor. hal 15.

Schlegel, H.G. dan K. Scuhmidt. 1994. Mikrobiologi Umum. Gajah Mada University Press. Yogyakarta. hal 468505.

Sumarsih, S. 2009. Diktat Kuliah Mikrobiolog Dasar. UPN press. Yogyakarta.

Widiastuti, R.R. 2007. Formulasi Pakan Buatan dengan Teknologi Fermentasi pada Budidaya Ikan Nila (Oreochromis niloticus Linn). Jurusan SITH-ITB. Bandung. hal 19. 